\author{
Arkadiusz Malkowski \\ West Pomernian University of Technology, Szczecin \\ e-mail: amalkowski@zut.edu.pl
}

ORCID: 0000-0003-2769-245X

\title{
BORDER TRADE AS A FACTOR \\ IN THE DEVELOPMENT \\ OF PERIPHERAL AREAS - THE EXAMPLE \\ OF POLAND'S EASTERN BORDERLAND
}

\section{HANDEL PRZYGRANICZNY \\ JAKO CZYNNIK ROZWOJU OBSZARÓW \\ PERYFERYJNYCH NA PRZYKŁADZIE \\ POGRANICZA WSCHODNIEGO POLSKI}

DOI: $10.15611 /$ pn.2019.6.06

JEL Classification: $\mathrm{O} 12$

Summary: Changes in the functions of borders affect the socio-economic changes taking place in border regions. They had been hitherto treated as peripheral due to the low level of economic development. The increased permeability of borders has revived contacts between communities divided by borders. The article presents selected results of research conducted by the author in four provinces of the Polish eastern border region. The aim of the research was to determine the volume of border trade and its significance for peripheral regions. In the article, the available data from GUS [Main Statistical Office] and the Border Guard as well as the results of author's own research based on CATI methodology were used. The conducted research indicates the importance of border trade for the development of Poland's eastern border regions. The vast majority of foreigners visiting this area declare shopping as their main purpose of travel. The vast majority of Russians, Belorussians, and Ukrainians shop within fifty kilometers from the border. An important factor impacting on the volume of border traffic is the functioning of preferential agreements on low border traffic.

Keywords: border trade, peripheral area, eastern borderland.

Streszczenie: Zmiany funkcji granic wpływają na przemiany społeczno-gospodarcze zachodzące w regionach przygranicznych. Dotychczas były one traktowane jako peryferyjne ze względu na niski poziom rozwoju gospodarczego. Wzrost przenikalności granic spowodował ożywienie kontaktów między społecznościami podzielonymi granicami. Artykuł przedstawia wybrane wyniki badań prowadzonych przez autora w 4 województwach wschodniego pogranicza Polski. Celem badań było określenie wielkości handlu przygranicznego i jego znaczenia dla obszarów peryferyjnych. W artykule wykorzystano dostępne dane GUS i Straży Granicznej oraz wyni- 
ki badań własnych autora opartych na metodologii CATI. Przeprowadzone badania wskazują na istotne znaczenie handlu przygranicznego dla rozwoju obszarów pogranicza wschodniego Polski. Zdecydowana większość cudzoziemców odwiedzających ten obszar deklaruje zakupy jako główny cel podróży. Zdecydowana większość Rosjan, Białorusinów i Ukraińców dokonuje zakupów w odległości do $50 \mathrm{~km}$ od granicy. Istotnym czynnikiem wpływającym na rozmiary ruchu granicznego jest funkcjonowanie preferencyjnych umów o małym ruchu granicznym.

Słowa kluczowe: handel przygraniczy, obszar peryferyjny, pogranicze wschodnie.

\section{Introduction}

In today's world, the functions of borders are essentially changing. More an more often they are becoming a space of contact and cooperation between communities divided by borders. A special example of transitioning from isolation to integration are the border regions in Europe.

The increasing permeability of borders is the result of the geopolitical transformations taking place in the integrating Europe, as well as changes in the mentality of communities of the divided areas. This is conducive to the development of various forms of activity, including those of a cross-border nature.

However, border regions remain a place in which aspirations for integration and isolation can clash, this is especially visible on the eastern border of the EU. As a result of the economic and political transformations during the twentieth and twenty-first centuries, it became a barrier between the rich West and the poorer East of Europe. It is in a way analogous to the "Iron Curtain" which for decades divided the post-war Europe. It has now been replaced by the "Golden Curtain," which, similarly to the iron one, divides communities both in the political and social dimension.

Experiences in breaking the barriers in cooperation between nations divided by borders encourage looking for various forms of easing border regimes and creating opportunities for the development of friendly coexistence, one of which is the development of border trade.

The increased flow of goods, services and people, made possible owing to the increasing permeability of borders, impact on the growth of cooperation across borders. Border regions, for decades considered peripheral, are becoming more and more attractive economically. The increasing commercial exchange in the border regions is both a dimension of globalization, but also glocalization.

\section{Purpose and research methods}

According to Heffner, research on the essence of the concept of border is conducted in many areas of science, and is interdisciplinary in nature (Heffner, 2010).

The purpose of this article is to present the changes of the function of Poland's eastern border and the impact of these changes on the development of border trade. 
The presented research is part of a broader scientific project, aimed at verifying the following hypothesis: "Border trade is a significant factor in the development of border regions." The research was conducted on the basis of data made available in public statistics by GUS [Main Statistical Office] and the Border Guard, as well as analysis of the available literature on the subject, including strategic studies.

From the point of view of verifying the research hypothesis, it was key to conduct surveys based on CATI methodology, with which 300 interviews were conducted with entrepreneurs from the Polish eastern border region. Questionnaire surveys were also performed on local governments within 50 kilometers from the eastern border. The research was conducted from June to October $2018^{1}$.

\section{Border permeability and the functioning of peripheral regions}

Border regions, due to their lower level of socio-economic development and the distance from decision-making centers, are often referred to as peripheral areas (Ciok, 2004; Barański, 2010). This is connected with specific historical and political conditions which influence the character of the borders (Baker, Milton, and Yearley, 1994). This translates onto the functioning of the local economy and influences the life of the region's community. The research conducted by the author indicates that border regions are usually characterized by highly adverse socio-economic features, and the change in the functions they perform becomes a factor actuating the social and economic processes occurring in the peripheral areas (Malkowski, 2015; Cheba and Szopik-Depczyńska, 2017). Literature studies provide numerous examples of border areas which due to the borders' functions are treated as peripheral (Anderson and O'Dowd, 1999; Chrzanowska and Drejerska, 2016).

The perception of borders as boundaries separating nations and economies was deeply transformed at the turn of the 20th and 21 st centuries. This especially concerns the European continent, integrating economically and politically. This entailed a change in the perception of traditional border functions, which can be defined as follows:

1. Military and political function - border defining sovereign territory.

2. Dividing function - border separating two communities with different cultures, systems of values, separating two different economic systems.

3. Filter function - as a barrier to the unwanted influx of foreigners, but also to goods and even ideas.

4. Integrating function - border integrating separated communities.

5. The most popular division of border regions with regard to the role of border as a barrier is the one proposed by $\mathrm{O}$. J. Martinez, dividing regions into four types (Martinez, 1994):

\footnotetext{
${ }^{1}$ The research was conducted in the following counties ['powiat']: Braniewo, Bartoszyce, Kętrzyn, Węgorzewo, Gołdap, Suwałki, Sejny, Augustów, Sokółka, Białystok, Hajnówka, Siemiatycze, Biała Podlaska, Włodawa, Chełm, Hrubieszów, Lubaczów, Jarosław, Przemyśl, Bieszczady.
} 
- isolated regions - the border is functionally closed, and impact across the border is completely or almost absent. Citizens of each country are total strangers to each other,

- coexisting regions - the border is open to some extent, which allows for the development of limited mutual impact and creating relations between citizens of countries,

- cooperating regions - economic and social complementarity stimulates the growth of cross-border influence. There is cooperation and friendly relations between citizens of divided countries,

- integrated border regions - the economies of both countries are functionally connected, the movement of people and goods across the border is unlimited. People living in the region have a sense of belonging to the same social system. The presented classifications are often used in the debate initiated in the 1990s, on the future of borders, cross-border cooperation, and development of border regions. The key element of these considerations is taking actions to increase the permeability of borders by building new border crossings, better organization or abolition of border controls, reducing the restrictiveness of customs and visa regulations, creating conditions for the development of cross-border entrepreneurship, etc.

In the case of Poland's eastern border region, it is difficult to determine which type of region we are dealing with. The area is largely diversified in terms of the processes and phenomena that occur there.

In the case of the border with the Russian Federation, cross-border cooperation is hampered by restrictive cross-border regulations, including the suspension of the local border traffic agreement in 2016. This part of the eastern border region should be classified as coexisting regions. There is still cooperation, although due to political reasons the border is not fully open.

In the case of the border with Belarus and Ukraine, the situation is somewhat different. Despite the limitations resulting from Poland's membership of the EU and the character of the European Communities' border policy towards the neighboring countries, this territory is a place of lively cooperation. Owing to scarce border traffic agreements and cooperation within the Euroregions, cooperation between communities residing in the border region is being developed. Various forms of cooperation of a socio-economic nature are being developed in this area. Therefore, in the case of the Polish-Belorussian and Polish-Ukrainian border regions, we can talk about cooperating regions referring to the division proposed by Martinez.

\section{Border traffic and development of peripheral regions}

The economic backwardness of peripheral areas and the accompanying adverse political conditions lead to a reduction in the level of competitiveness of these areas (Krugman, 1997; Dziemianowicz and Herbst, 2002). They are not able to compete with other regions not only in terms of goods and services, but also in terms of 
competing over production factors. That is why social problems are characteristic for them, namely migration, depopulation, ageing of societies, development of social and economic dysfunctions such as unemployment, and low level of investment (Aria, Gaeta, and Marani, 2018; Dubois, 2016).

The conducted research indicates that the processes taking place at the borders significantly affect the activity of borderland residents and the nature of the border regions (Malkowska, 2013). Changes in the role of the eastern border and its increased permeability contributed to its regular crossing by border residents (Dziemianowicz and Herbst, 2002). Borderland residents are increasingly willing to cross the border for shopping and tourist purposes (Więckowski, 2010).

In 2017 the estimated number of crossings at the Polish border amounted to 287.1 million. Over 171.6 million foreigners and 115.5 million Poles crossed the border. Over $74 \%$ of those crossing the border used the land border crossing points between Poland and the EU, and $12.5 \%$ crossed the EU's external border (the border with Russia, Belarus, and Ukraine). Among the foreigners crossing individual sections of the land border of Poland, most were citizens of the neighboring country. For instance, at the border with Ukraine, $96.6 \%$ were citizens of Ukraine, and at the border with Russia, $90.5 \%$ were citizens of Russia.

Compared to 2014, the number of foreigners crossing the border increased. In 2014, over 151 million foreigners crossed the Polish borders, and in 2017 over 170 million, which means an increase of $13 \%$.

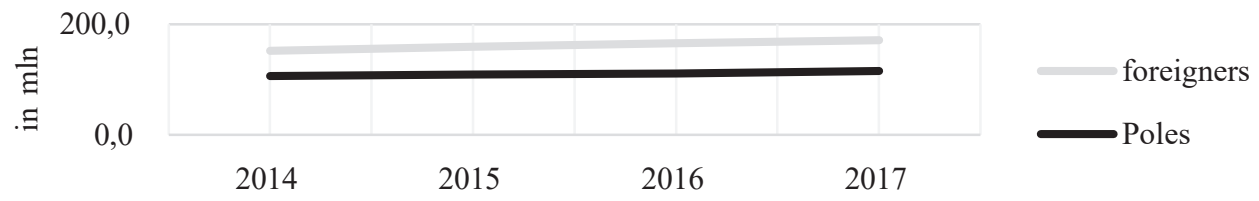

Fig. 1. Border traffic in 2014-2017

Source: own study on the basis of data from the Border Guard.

The largest increase in border traffic in Poland regarding the EU external border occurred on the border with Ukraine. Compared to 2014, the Polish-Ukrainian border was crossed by over 5 million more foreigners in 2017. In the case of the border with Belarus, the number of people crossing the border increased by 450,000 people. However, for the Polish-Russian border, a decrease in the number of people crossing the border was observed.

In 2014 more than 3.3 million foreigners crossed the border with the Kaliningrad Oblast (Polish-Russian border), and in 2017 only 2.5 million (a decrease of $24 \%$ ). The unfavorable situation on the border with Russia is the effect of the suspension of the agreement on Local Border Movement between Poland and the Kaliningrad Oblast in 2016. This increased the costs associated with crossing the border related to the 
need to obtain a costly visa. This particularly affected the less affluent residents of the region and had an impact on the number of Poles visiting Kaliningrad.

According to data from the border services in 2017, there were almost 6 times more checks on the Polish-Ukrainian border than on the Polish-Russian border and 2.5 times more than on the Polish-Belarusian border. The increase in border traffic with Ukraine is the effect of the opening of the Polish labor market to Ukrainian workers, and the possibility for residents of border areas to buy affordable products in Poland.

The research conducted by the author indicates the close relationship between the volume of border traffic of foreigners and the socio-economic situation of the border areas. The conducted questionnaire surveys showed that $89 \%$ of entrepreneurs based in a province located directly at the border recognized that the increase in border traffic has a positive effect on the economic situation in the region. The greatest impact of border traffic on the economic situation of the region was indicated by entrepreneurs from the Warmia-Mazury province [voivodeship] (95\% of responses) and the Podkarpackie province (96\%).

The results of the survey confirmed the research on the motives for crossing the border by foreigners in 2017. The vast majority of respondents cross the border for a very short period of time. Over $84 \%$ of foreigners and $87 \%$ of Poles leave and return in one day. In 2017, 94\% of foreigners visited Poland to make purchases. In 2014 the same purpose was declared by $93 \%$ of those crossing the border. In the case of Poles, $30 \%$ of those crossing the border went shopping in 2017 on the other side of the border.

Expenditure of foreigners in Poland are treated as an additional infusion of money, extremely important for the local economy. It should be noted that the areas of the eastern border of Poland are primarily agricultural regions with a poorly developed industry and service sphere. The underdevelopment of the local economy mainly concerns areas remote from regional growth centers such as Suwałki, Białystok, Biała Podlaska, Chełm, Zamość, and Przemyśl. Despite the favorable location in this area, industry and modern agri-food processing has not developed yet. The condition of the economy of the region of the eastern borderland of Poland is represented by macroeconomic data on GDP per capita and the unemployment rate, see Table 1.

Table 1. Basic macroeconomic data for the eastern borderland of Poland in 2017

\begin{tabular}{|l|c|c|c|}
\hline \multicolumn{1}{|c|}{ Region } & $\begin{array}{c}\text { GDP per citizen } \\
\text { in \% } \\
\text { (current prices) }\end{array}$ & $\begin{array}{c}\text { Share in creating the } \\
\text { GDP in \% } \\
\text { (current prices) }\end{array}$ & $\begin{array}{c}\text { Unemployment rate } \\
\text { in \% }\end{array}$ \\
\hline Poland & 100 & - & 6.6 \\
\hline Warmia-Masuria & 70.4 & 2.6 & 11.7 \\
\hline Podlaskie & 71.8 & 2.2 & 8.5 \\
\hline Lubelskie & 68.9 & 3.8 & 8.8 \\
\hline Podkarpackie & 69.8 & 3.9 & 9.7 \\
\hline
\end{tabular}

Source: own study on the basis of data from (Border traffic and expenditure... ). 
The high unemployment rate and the low share in creating GDP characterizing this area indicate the weakness of the potential of the local economy.

The shopping nature of border traffic on the eastern border of Poland is primarily determined by the attractiveness of the prices and the availability of diversified products and services on offer. According to GUS data, as many as $65.9 \%$ of Russians visiting Poland declare shopping as their purpose, and 13.2\% declare tourism and recreation, see Table 2. As many as $83.6 \%$ of Belarusians crossing the border indicated shopping as the purpose of their visit. At the same time, only $1.8 \%$ of them did so for recreational purposes. The largest percentage of those crossing the border to make purchases concerned the Polish-Ukrainian border. As many as $87.3 \%$ of Ukrainians declared shopping as the purpose of their visit to Poland.

Table 2. The declared purpose of the visit of foreigners crossing the eastern border of Poland in 2017

\begin{tabular}{|l|c|c|c|c|c|}
\hline \multirow{2}{*}{$\begin{array}{c}\text { Section of the } \\
\text { border with }\end{array}$} & \multicolumn{5}{|c|}{ Purpose of visit } \\
\cline { 2 - 6 } & Shopping & $\begin{array}{c}\text { Leisure, } \\
\text { recreation }\end{array}$ & $\begin{array}{c}\text { Visiting } \\
\text { family, relatives }\end{array}$ & Transit & $\begin{array}{c}\text { Business } \\
\text { reasons }\end{array}$ \\
\hline Russia & 65.9 & 13.2 & 3.0 & 10.4 & 4.9 \\
\hline Belarus & 83.6 & 1.8 & 7.1 & 4.1 & 2.3 \\
\hline Ukraine & 87.6 & 0.6 & 2.2 & 2.0 & 5.3 \\
\hline
\end{tabular}

Source: own study on the basis of data from (Border traffic and expenditure... ).

The quality of products is also a factor in making purchases in Poland. Over $56 \%$ of the surveyed foreigners visiting shopping centers by the border indicated that products purchased in Poland had an attractive price and good quality (Malkowski and Malkowska, 2011). At the same time, the surveyed entrepreneurs point to the changing shopping preferences of foreigners. Increasingly, they are buying more expensive, higher quality products in Poland, including mainly furniture, home appliances and construction materials using the Tax Free system. An increasing number of sellers are offering foreign customers the opportunity to recover VAT. The basis for the refund is the traveler's presentation of a document issued by the seller, on which the customs office confirmed the export of the goods. The nature of the products purchased in Poland allows foreigners to buy attractive products cheaper by the amount of VAT, which is $23 \%$ on most products. This makes shopping in Poland really attractive.

As many as $30 \%$ of the surveyed entrepreneurs from border towns indicated that foreigners constituted up to $40 \%$ of their clients, and the range of products and services they offered was adapted to the needs of buyers outside the EU's external border. Food is a special example here. This applies above all to the Polish-Russian and Polish-Belarusian borders, where increased demand of foreigners for cheap food products was observed, in particular meat, sweets, and vegetable fats.

For Poles crossing the EU external border, purchases of fuel and cigarettes are still the primary purpose of trips. In 2017 they could save on average around 50\% 
per 1 liter of diesel fuel, which makes shopping over the eastern border extremely profitable. A similar situation applies to cigarettes, which are about $65 \%$ cheaper. The differences in the prices of excise goods are the main motive for trips, and at the same time the basis for the development of illegal trade.

The volume of border traffic has meant that the expenditure associated with it make an important factor supporting the local economy, although the effects are difficult to measure. As many as $89 \%$ of the surveyed border self-governments indicated that border trade and border tourism were important for the local development. This is reflected in the strategies of $56 \%$ of the surveyed local governments, which directly or through projects assumed for implementation relate to the use of the border location in the development of entrepreneurship and the creation of new jobs.

The estimated value of goods and services purchased in Poland by foreigners in 2017 amounted to PLN 41.5 billion, and expenditure incurred abroad by Polish residents - PLN 20.1 billion.

In the period 2014-2017, average expenditure incurred by foreigners in Poland increased from PLN 478 to PLN 493, while for Poles shopping abroad this also increased from PLN 347 in 2014 to PLN 354 in 2017.

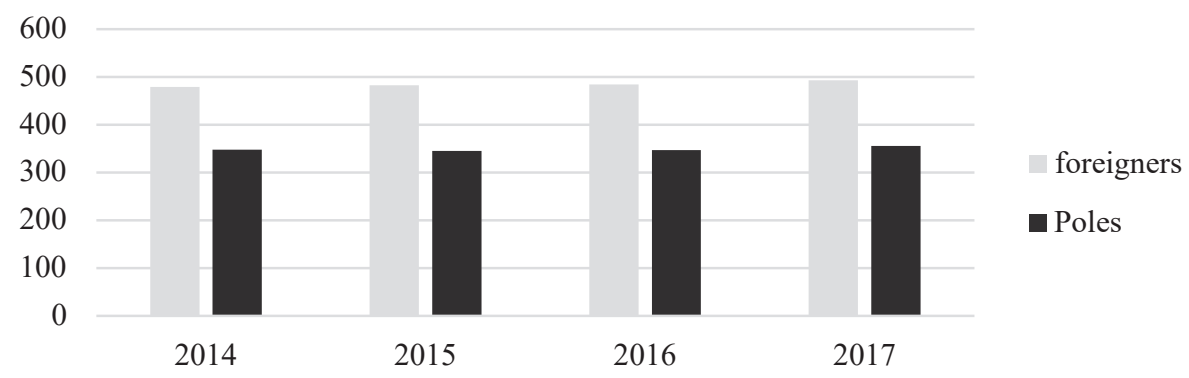

Fig. 2. Average expenditure of Poles and foreigners crossing the border in PLN

Source: own study.

In the case of the eastern border of Poland, the types of expenditure incurred by foreigners crossing the external border of the EU varied. In 2017 the citizens of Ukraine spent the most on shopping in Poland. They spent over PLN 750 on the purchase of products and services per one person crossing the border. In the same period, the Russians spent PLN 455 and Belarusians spent PLN 624 per person.

In the analyzed period, only in the case of the border with Ukraine there was an increase in the expenditure incurred by foreigners in Poland, from PLN 734 in 2014 to PLN 750 in 2017. The largest decrease in expenditure incurred in Poland concerns Belarusian citizens, who in 2014 spent an average of PLN 831 in Poland, and in 2017 only PLN 624. This is due to the unstable economic situation in Belarus and the lowering of the value of the Belarusian currency which has made shopping in Poland less profitable. 


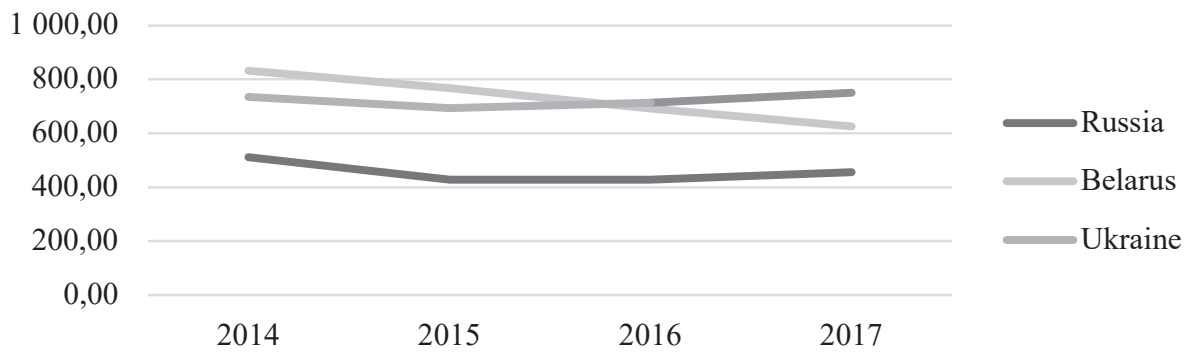

Fig. 3. Average expenditure of foreigners crossing the eastern border of Poland Source: own study.

The observations clearly show that expenditure incurred by foreigners as part of border traffic are an important factor in the development of the border area. In 2017, Russian citizens left over PLN 415 million in Poland, of which PLN 149.8 million (26\%) was spent on food and alcoholic beverages. At the same time, Belarusian citizens spent 2.4 billion. PLN, of which PLN 333 million (13.6\%) was on the purchase of food and alcohol. The citizens of Ukraine spent the most on purchases in Poland, as much as 7 billion PLN, of which PLN 852 million (11.6\%) was for the purchase of food and alcohol.

Non-food products constituted the highest value among foreigners' expenditure crossing the eastern border of Poland. Russians spent PLN 340 million (59.8\%) on their purchases, Belarusians over PLN 2 billion (81.9\%), and Ukrainians spent PLN 6.6 billion ( $85.7 \%$ ). The vast majority of expenditure was incurred by foreigners within a $50 \mathrm{~km}$ range from the border. In the case of Russians, over $73 \%$ of purchases made in Poland are made within $50 \mathrm{~km}$ of the border crossing, including $64 \%$ within $30 \mathrm{~km}$. By far the largest percentage of expenditure in the border area came from Belarusian citizens. In the zone up to $50 \mathrm{~km}$ from the border, Belarusians leave as much as $96.6 \%$ of their spending in Poland (respectively $89.9 \%$ in the $30-\mathrm{km}$ range). In the Polish-Ukrainian border area, $91 \%$ of expenditure of Ukrainian citizens in Poland are incurred at a distance of less than $50 \mathrm{~km}$ from the border $(89 \%$ in the $30-\mathrm{km}$ range, respectively). This means that in an area $50 \mathrm{~km}$ away from the Russian border, revenues related only to the shopping character of cross-border travel of Russian citizens to Poland are estimated at over PLN 415 million. In the case of the border with Belarus, over PLN 2.3 billion remains in the border zone. The most benefit from border traffic is gained by the Polish-Ukrainian border area, in which over PLN 6 billion remains from purchases made by Ukrainian citizens in Poland. This indicates that border trade is a significant factor in the development of local economy. 


\section{Conclusion}

The areas of the eastern borderland of Poland are also peripheral regions of the European Union. The processes of integration and isolation that occur simultaneously pose a number of new socio-economic challenges for those regions. The peripheral nature of the region has meant that both in terms of share in the creation of GDP and the size of unemployment it is among the most problematic areas in Poland.

Changes in the function of the border and the accompanying development of border traffic provide an opportunity to intensify the development of the eastern borderland of Poland. The developing border trade allows for gaining new revenues in peripheral areas in which industry or modern processing has not developed yet.

The conducted research has demonstrated that border trade is important for the development of the border area. In particular this applies to the area within $50 \mathrm{~km}$ from the border, in which purchases made by foreigners visiting Poland are concentrated. The vast majority of citizens of Russia, Belarus and Ukraine cross the Polish border to make purchases, and of these, Ukrainians spend the most in Poland, and Russians the least.

The example of the Polish-Russian border shows that the suspension of the Local Border Movement agreement adversely affected both the volume of border traffic and the expenditure of Russians in Poland. It seems advisable to restore preferences regarding crossing the border with the Kaliningrad district (Oblast).

\section{Bibliography}

Anderson, J., O’Dowd, L. (1999). Borders, border regions and territoriality: Contradictory meanings, changing significance. Regional Studies, 33(7), 593-604.

Aria, M., Gaeta, G. L., and Marani, U. (2018). Similarities and differences in competitiveness among European NUTS2 Regions: An empirical analysis based on 2010-2013 data. Social Indicators Research, 1-20.

Baker, S., Milton, K., and Yearley, S. (Eds.). (1994). Protecting the Periphery: Environmental Policy in Peripheral Regions of the European Union. Routledge.

Barański, J. (2010). Granica w badaniach geograficznych - definicja i próby klasyfikacji. Przeglad Geograficzny, (82), 489-508.

Border traffic and expenditure by foreigners in Poland and Poles abroad in 2017, Statistics Poland, Statistical Office in Rzeszów.

Cheba, K., and Szopik-Depczyńska, K. (2017). Multidimensional comparative analysis of the competitive capacity of the European Union countries and geographical regions. Oeconomica Copernicana, 8(4), 487-504.

Chrzanowska, M., and Drejerska, N. (2016). Statistical Comparative Analysis of Socio-Economic Development Level of Polish Border Regions (NUTS 3). In: Proceedings of the International Scientific Conference on Quantitative Methods in Economics-Multiple Criteria Decision Making XVIII, 170-176.

Ciok, S. (2004). Pogranicze polsko-niemieckie. Problemy wspótpracy transgranicznej. Wrocław: Wydawnictwo Uniwersytetu Wrocławskiego. 
Dubois, A., (2016). Transnationalising entrepreneurship in a peripheral region - the translocal embeddedness paradigm. Journal of Rural Studies, (46), 1-11.

Dziemianowicz, W., and Herbst, M. (2002). Rola granicy państwa w rozwoju obszarów przygranicznych - przykład Terespola. Studia Regionalne i Lokalne, (2-3), 111-127.

Heffner, K. (2010). Granica - rozwój instytucji (definicje, etymologia, typologia). In: S.M. Grochalski (Ed.), Ewolucja instytucji granicy we wspótczesnej Europie (pp. 77-100). Opole: Wydawnictwo Uniwersytetu Opolskiego.

Krugman, P. R. (1997). Development, geography, and economic theory. Vol. 6. MIT Press.

Malkowska, A. (2013). Strategia rozwoju euroregionu Pomerania a budowa konkurencyjnego regionu przygranicznego. Prace Naukowe Uniwersytetu Ekonomicznego we Wrocławiu, (307), 353-362.

Malkowski, A. (2015). Koncepcje rozwoju społeczno-gospodarczego obszarów przygranicznych. Prace Naukowe Uniwersytetu Ekonomicznego we Wrocławiu, (402), 210-219.

Malkowski, A., and Malkowska, A. (2011). Konkurencyjność obszarów peryferyjnych na przykładzie pogranicza polsko-niemieckiego. Journal of Agribusiness and Rural Development, 02(20), 55-63.

Martinez, O. J. (1994). The dynamics of border interaction. In: Dh. Schofield (Ed.), Global boundaries, world boundaries. Vol. 1, London.

Więckowski, M. (2010). Turystyka na obszarach przygranicznych Polski, Prace Geograficzne, (224). IGiPZ PAN. 